American Journal of Environmental Sciences 4 (8): 103-110, 2008

ISSN 1553-345X

(C) 2008 Science Publications

\title{
Behaviour of Main Microbiological Parameters And of Enteric Microorganisms During the Composting of Municipal Solid Wastes and Sewage Sludge in A Semi-Industrial Composting Plant
}

\author{
Olfa Fourti, Naceur Jedidi and Abdenaceur Hassen \\ Centre des Recherches et des Technologies des Eaux, Laboratoire Traitement et Recyclage, \\ BP 24 -1082, Cité Mahrajène, Tunis, Tunisie
}

\begin{abstract}
This study was focused on the microbiological aspects of composting and on the behaviour of main prevalent microbial communities (non-pathogenic and selected pathogenic bacteria) during the composting process of municipal solid wastes and sewage sludge in a semi-industrial composting plant. Results showed that the dehydrogenase activity and Biomass $\mathrm{C} / \mathrm{Biomass} \mathrm{N}$ ratio showed a noticeable increase in the two windrows W1 (100\% of municipal solid wastes) and W2 (60\% of municipal solid wastes and $40 \%$ of dried sewage sludge) during the thermophilic phase $\left(\geq 45^{\circ} \mathrm{C}\right.$ for 100 days) and marked a high microbial activity during this period of the composting process. During the thermophilic phase, the removal of faecal indicator bacteria is in order of $2 \mathrm{Ulog}_{10}$, and a total absence of Staphylococcus aureus and Salmonella was observed. The re-emergence of faecal indicator bacteria at the end of the composting progress (cooling step) could constitute a major problem for the agricultural use of compost.
\end{abstract}

Keywords: $\quad$ Solid wastes, Sewage sludge, Compost, Temperature, Pathogenic bacteria, Faecal indicator bacteria.

\section{INTRODUCTION}

Composting is basically a process of different organic solid wastes decomposition. The decomposition process is carried out by various microorganisms including mainly bacteria and actinomycetes. During composting, microorganisms degrade organic matter and produce various products such as carbon dioxide and water. Release of heat and production of relatively stable organic compounds (humic substances) result from this process ${ }^{[1]}$.

Different communities of microorganisms predominate during the various composting phases. Initial decomposition is carried out by mesophilic microorganisms, which rapidly biodegrade the soluble and easily degradable compounds. The release of heat causes a rapid rise of temperature. As the temperature rises above $40^{\circ} \mathrm{C}$, mesophilic microorganisms become less competitive and are replaced by thermophilic organisms ${ }^{[2]}$. At temperatures of $55^{\circ} \mathrm{C}$ and above, many microorganisms including human or plant pathogens are destroyed. Generally, for developing rapid and efficient solid waste decomposition, temperatures must not exceed $60^{\circ} \mathrm{C}^{[1]}$. During the thermophilic phase, high temperatures accelerate the breakdown of proteins, fats and complex carbohydrates such as cellulose and hemicellulose. As these high-energy compounds become exhausted, the compost temperature gradually decreases and mesophilic microorganisms once again take over the other types of microorganisms during the final phase of maturation.

The aim of this study was mainly focused on the behaviour of main microbiological parameters and of enteric microorganisms during the composting of municipal solid wastes and sewage sludge in a semiindustrial composting plant.

\section{MATERIALS AND METHODS}

Preparation of windrows: The study was performed in the composting plant of Beja located $100 \mathrm{~km}$ from the north of Tunis, using two types of windrows: (i) the first windrow W1 constituted with $100 \%$ of municipal solid wastes, and (ii) the second windrow W2 composed by weight of $60 \%$ of municipal solid wastes and $40 \%$ of dried sewage sludge.

Municipal solid wastes from the Erriadh city of Beja were pre-selected at source (household pre-selection with average physical-chemical characteristics, humidity $=60 \%$, organic matter $=30 \%$ dry weight and $\mathrm{C} / \mathrm{N}=32$ )

Corresponding Author: Olfa fourti, Centre des Recherches et des Technologies des Eaux, Laboratoire Traitement et Recyclage, BP 24 -1082, Cité Mahrajène, Tunis, Tunisie 
and subjected to an accurately manual sorting in the plant, weighted and put on the composting platform, in the form of windrows of $7.5 \times 3 \times 1.5 \mathrm{~m}$ (length $\mathrm{x}$ width $\mathrm{x}$ height, respectively). Stabilized sewage sludge from anaerobic digestion of the urban wastewater treatment plant of Beja was integrated in the process at the dry state (with average physical-chemical characteristics, humidity $=30 \%$, organic matter $=65 \%$ dry weight and $\mathrm{C} / \mathrm{N}=12.5$ ) and primarily for the cover of windrow $\mathrm{W} 2$.

Temperature and humidity were controlled daily. When the mean temperature recorded in the different depths (depths 20, 40 and $60 \mathrm{~cm}$ ) of the pile averaged $55^{\circ} \mathrm{C}$ (using a thermo-couple iron-constantan type $\mathrm{J}$ ), the windrow was turned and watered. These operations of turning and watering with tap water were performed almost twice monthly in considering ambient temperature.

\section{Physical and chemical parameters determinations:} Humidity was performed using $500 \mathrm{~g}$ of fresh solid waste according to the differential weight of fresh and dry waste at $105^{\circ} \mathrm{C}$. Total nitrogen was measured by the Kjeldahl method ${ }^{[3]}$ and total organic carbon by the wet dichromate oxidation method ${ }^{[4]}$. The dehydrogenase activity expressed as triphenylformazan unit was measured according to Tabatabai ${ }^{[5]}$.

Solid waste microbial $\mathrm{C}$ and $\mathrm{N}$ biomasses were evaluated using the fumigation extraction method ${ }^{[6]}$. Duplicate samples $(10 \mathrm{~g})$ of the treated composts and control were fumigated with ethanol-free $\mathrm{CHCl}_{3}$. Fumigated and non-fumigated compost samples were extracted with $0.5 \mathrm{M} \mathrm{K}_{2} \mathrm{SO}_{4}$ and organic $\mathrm{C}$ quantified by oxidation with $0.0667 \mathrm{M} \mathrm{K}_{2} \mathrm{Cr}_{2} \mathrm{O}_{7}$ and subsequent back-titration of the unreduced dichromate. Microbial biomass $\mathrm{C}$ content was estimated as follows: $\mathrm{B}_{\mathrm{C}}=2.64$ $\mathrm{x} \mathrm{E}_{\mathrm{C}}$, where $\mathrm{E}_{\mathrm{C}}$ is the difference between the organic $\mathrm{C}$ extracted from the fumigated and non-fumigated treatments $^{[7]}$. Total $\mathrm{N}$ in extracts was determined according to the Kjeldahl method as described by Brookes et al. ${ }^{[8]}$. Biomass $\mathrm{N}\left(\mathrm{B}_{\mathrm{N}}\right)$ was calculated from the relationship $B_{N}=0.68 \times E_{N}$, where $E_{N}$ is the difference between $\mathrm{N}$ extracted from the fumigated and non-fumigated samples. Amounts of microbial biomass $\mathrm{C}$ or $\mathrm{N}$ are expressed (mg C or $\mathrm{N} / \mathrm{kg}$ dry weight) and represent average of three determinations.

Microbial counts: Sampling of fresh waste or compost was performed as recommended by Hachicha et al. ${ }^{[9]}$ and $10 \mathrm{~g}$ were dispersed into $90 \mathrm{ml}$ of sterile distilled water. They were then submitted to mechanical vigorously shaking for $2 \mathrm{~h}$ to crush compost aggregates (Edmund Buhler, Type Swim KL-2 m. Uhr: 1-120 m,
Germany) and the suspensions were used for microbial counts. Hassen et al. ${ }^{[2]}$ consider this dispersion step of great importance because all the microbial cells and endospores tend to be aggregated and adsorbed to various waste particles.

The bacteriological analyses were done both quantitatively and qualitatively: (i) counting the number of total viable-cultivable mesophilic bacteria, spore-forming bacteria, actinomycetes and faecal indicator bacteria such as Escherichia coli and faecal streptococci, and (ii) detecting certain pathogenic species such as Salmonella and Staphylococci, particularly Staphylococcus aureus. All type of suspected pathogen colonies isolated throughout the experimentation was stained by the Gram method. All waste samples were stored at $+4^{\circ} \mathrm{C}$ and assayed in triplicates at the latest during $72 \mathrm{~h}$.

Enumeration of mesophilic actinomycetes: The dilution plate count has been used for mesophilic actinomycetes enumeration and isolation. The formation of coenocytic mycelium means that only approximations of viable propagules can be made due to fragmentation. The Arginine glycerol salts agar recommended by El-Nakeeb and Lechevalier ${ }^{[10]}$ is used and incubation is done at $28^{\circ} \mathrm{C}$ for 7 to 20 days depending on the extent of overgrowth by fungi and bacteria.

Enumeration of faecal indicator bacteria: Numbers of $E$. coli and faecal streptococci were determined with the most probable number (MPN) method according to Turco $^{[11]}$ and Rodier ${ }^{[12]}$. The MPN of bacteria was calculated using the table of De Man ${ }^{[13]}$.

Enumeration of total viable-cultivable mesophilic bacteria: Total indigenous viable-cultivable mesophilic bacteria from different suspension-dilution of waste samples were enumerated by the pour plate technique on Tryptic soy agar (Pasteur Production, Paris). The plates were incubated for 3 days at $28^{\circ} \mathrm{C}$.

Enumeration of spore-forming bacteria: The protocol of count of spore-forming bacteria includes several steps from selection by applying heat to destroy vegetative bacteria $\left(80^{\circ} \mathrm{C}\right.$ for $\left.10 \mathrm{~min}\right)$ to the indication by spreading volumes of the sample into Tryptic soy agar (Pasteur Production, Paris) followed by incubation at $37^{\circ} \mathrm{C}$ for 3 days. Spore-counting bacteria were expressed as colony-forming units per gram (CFUs / g) of dry weight of compost. 
Detection of Staphylococci: Staphylococcus detection was carried out on Baird-Parker medium incubated at $37^{\circ} \mathrm{C}$ for $48 \mathrm{~h}$. Convex, brilliant, black colonies surrounded by a clear halo were purified on Brain-Heart Infusion agar (Pasteur Production, Paris). The pathogenic character of the isolates was checked by: (i) the coagulase test in coagulase mannitol broth supplemented with freeze-dried rabbit plasma (Diagnostic Pasteur, Paris) and (ii) the DNAase test by culturing suspect colonies on medium DNAase agar at $37^{\circ} \mathrm{C}$ for $48 \mathrm{~h}$, and flooding the plates with $\mathrm{HCl}(1 \mathrm{~N})$. Colonies with a transparent halo were DNAase positive.

Detection of Salmonella: The detection of Salmonella was done using two selective media, the RappaportVassiliadis and Selenite broth. Salmonella-Shigella agar (SS agar) was used as a growth medium. Suspect colonies were sub-cultured for confirmation on UreaIndol and Kligler media (Pasteur Production, Paris) with 2 to $3 \mathrm{~h}$ incubation for the first medium and $24 \mathrm{~h}$ for the second. When tests were positive, the Lysine Decarboxylase (LDC) and Ortho-Nitro-ParaGalactoside tests (Pasteur Production, Paris) were carried out, and the API 20E system is tested for all presumed Salmonella isolates.

\section{RESULTS}

Evolution of temperature during solid waste composting process: The fluctuation of temperature recorded in the two windrows during the composting process showed the three classic steps (Fig. 1):

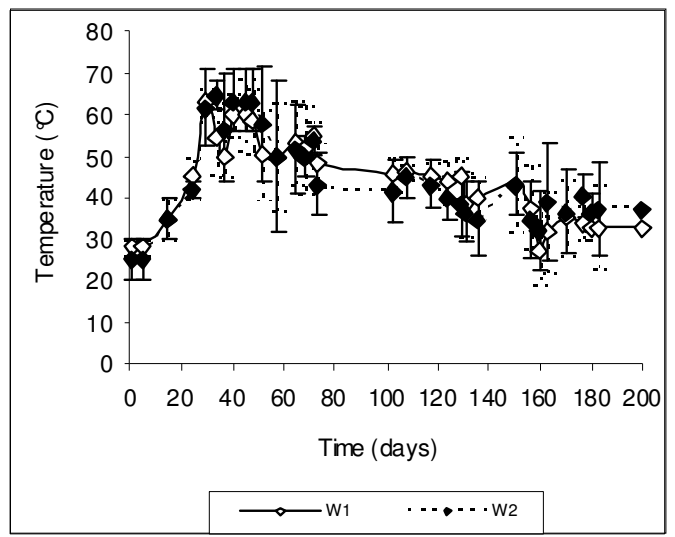

Fig. 1: Progress of temperature over time in windrows $\mathrm{W} 1$ and $\mathrm{W} 2$.

$\pm:$ Standard deviation, $\mathrm{n}=3$.

Mesophilic phase: Mesophilic microorganisms in waste windrows tended to increase during the first 25 days of the composting process, while the temperature increased gradually to reach $25-45^{\circ} \mathrm{C}$ as a consequence of biodegradation of organic compounds.

Thermophilic phase: This important step occurred between 30 and 130 days of the composting process, during which the temperature exceed the tolerance limit of mesophilic microorganisms $\left(\leq 45^{\circ} \mathrm{C}\right)$. The passage to the thermophilic phase for the two piles could be attributed to high numbers of indigenous microorganisms which attack rapidly the soluble, the readily degradable compounds, the high content of available nutrients and the relatively small size of organic fraction particles. As the temperature rises above about $40^{\circ} \mathrm{C}$, the mesophilic microorganisms become less competitive and are replaced by others that are thermophilic.

Cooling phase: The temperature began to decrease after the $19^{\text {th }}$ week. This decrease resulted from a beginning depletion of organic matters. During this phase, the $\mathrm{C} / \mathrm{N}$ ratio in the two windrows tended to stabilize (Fig. 2). By the end of fifth month of composting, average temperatures inside the two windrows marked a real decrease with values of approximately $33^{\circ} \mathrm{C}$. The temperature remained no change in spite of watering and turning of the windrows.

C/N ratio: In this study, the values of $\mathrm{C} / \mathrm{N}$ ratio appeared generally higher in the windrow W1 than in the windrow W2, these values decrease from 32 at the beginning of the composting process to 18.6 at the end of the process for windrow W1 and from 28.5 to 14.6 for windrow W2 (Fig. 2). The use of sewage sludge can explain this relatively feeble $\mathrm{C} / \mathrm{N}$ ratio recorded throughout the composting process in windrow W2. Indeed, sewage sludge is known by their high nitrogen content $(\mathrm{C} / \mathrm{N}$ varied between 5 to10) as compared to the one generally registered in municipal solid waste of Beja ( $\mathrm{C} / \mathrm{N}$ varied between 25 to 35). Many authors reported that a $\mathrm{C} / \mathrm{N}$ ratio below 20 is indicative of an acceptable maturity ${ }^{[14]}$.

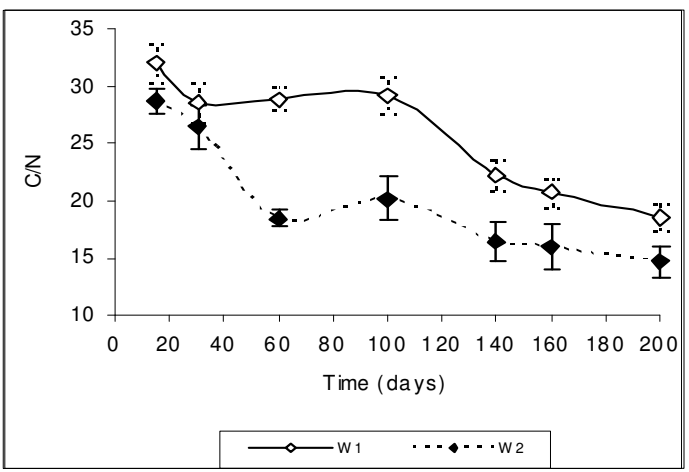

Fig. 2: $\quad$ Progress of $\mathrm{C} / \mathrm{N}$ ratio over time in windrows $\mathrm{W} 1$ and $\mathrm{W} 2$ 
Dehydrogenase activity: The dehydrogenase activity generally showed an appreciable increase during the period extending between 50 and 140 days and corresponding to the thermophilic phase of the composting process. The registered values of the dehydrogenase activity during this phase were on average of 8 and $7 \mathrm{mg}$ (triphenylformazan) TPF / g waste dry weights (WDW) / day (d) for windrows W1 and W2, respectively (Fig. 3). This activity was very weak during the mesophilic and the cooling phase, and was generally below $4 \mathrm{mg}$ TPF / g WDW / d for the two windrows. On the other hand, this activity was slightly higher in the windrow free of sludge than in the one with sludge.

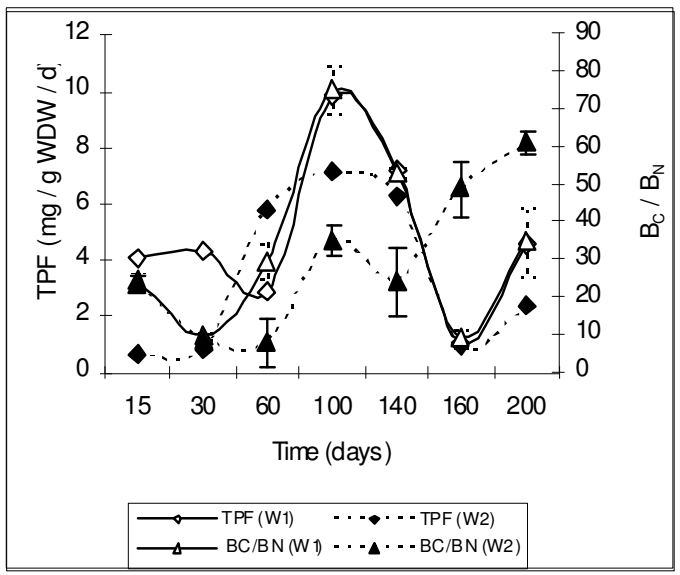

Fig. 3: Progress of dehydrogenase activity and $B_{C} / B_{N}$ ratio over time in windrows $\mathrm{W} 1$ and $\mathrm{W} 2$

$\mathbf{B}_{C} / \mathbf{B}_{N}$ ratio: The $B_{C} / B_{N}$ ratio represents the biological activity balance of the compost and a high $\mathrm{B}_{\mathrm{C}} / \mathrm{B}_{\mathrm{N}}$ ratio is equivalent to a high microbial heterogeneity, diversity and synonym of an important biological activity $^{[15,16,17]}$. According to Fig. 3 , this ratio showed a real increase during the thermophilic phase in the two windrows. A minimal value corresponding to the beginning of the cooling phase is recorded and followed by a clear increase of this $\mathrm{B}_{C} / \mathrm{B}_{\mathrm{N}}$ ratio during the maturation phase.

Total viable-cultivable mesophilic bacteria: The number of colony forming units (CFUs) of total viablecultivable mesophilic bacteria, at $28^{\circ} \mathrm{C}$ on Tryptic soy agar were around $9.7 \mathrm{Ulog}_{10} \mathrm{CFUs} / \mathrm{g}$ WDW at the start of the process for both windrows W1 and W2 (Fig. 4).

After about four weeks, the number of total viablecultivable mesophilic bacteria start to decrease gradually. This decrease could be attributed to the increase of temperature, loss of readily biodegradable substrate, or loss of moisture during the thermophilic phase. A phase of resumption appears later at the end of the fermentation process and can result from the recolonisation of the wastes by mesophilic microorganisms after the progressive cooling of windrows. The number of total viable-cultivable mesophilic microorganisms in windrows $\mathrm{W} 1$ and $\mathrm{W} 2$ reaches, at the end of the process, 9.7 and $9.2 \mathrm{Ulog}_{10}$ CFUs / g WDW, respectively.

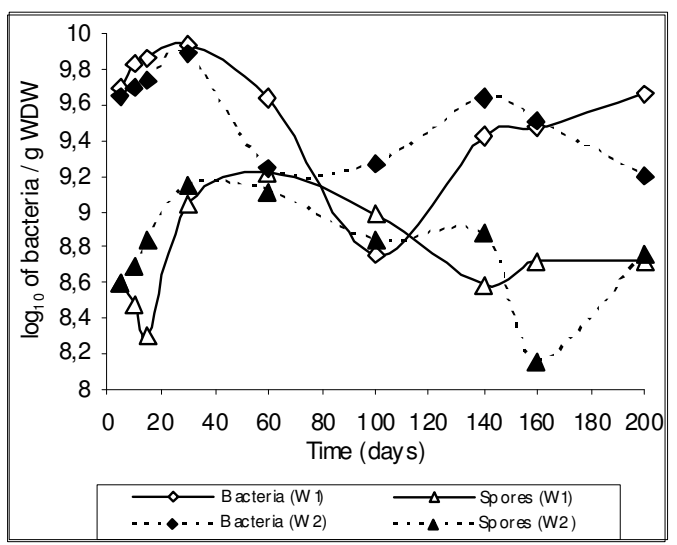

Fig. 4: Progress of total viable-cultivable mesophilic bacteria and spore-forming bacteria over time in windrows $\mathrm{W} 1$ and $\mathrm{W} 2$

Spore-forming bacteria: The Fig. 4 shows that there is a notable increase of the number of spores during the thermophilic phase. The increase of spore numbers is certainly linked to a rise of the temperature in the windrows and to the unfavourable conditions such as lack of nutriments, competition and antagonism phenomenon that promote bacterial sporulation. The temperature and the number of spore-forming bacteria progress in similar and in parallel into the two windrows $\mathrm{W} 1$ and $\mathrm{W} 2$. When conditions in the wastes become less stressful ( $\mathrm{T}, \mathrm{O}_{2}$, moisture, etc.), a net decrease of the number of spores is observed as a result of spore germination. In the same way, turning the wastes can facilitate the germination of spores.

Actinomycetes: The number of mesophilic actinomycetes showed in this study no major variation during all the composting process and fluctuated weakly between 8.8 to $8.2 \mathrm{Ulog}_{10} \mathrm{CFUs} / \mathrm{g}$ WDW and 7.7 to $7.4 \mathrm{Ulog}_{10}$ CFUs / g WDW for W1 and W2, respectively.

Faecal indicator bacteria: Escherichia coli: During all the composting process, the number of Escherichia coli was higher in the windrow $\mathrm{W} 1$ than in the windrow W2 
(Fig. 5). For windrow W2, the number of Escherichia coli fluctuated between 5.8 and $6.2 \operatorname{Ulog}_{10}$ CFUs / g WDW). For windrow W1, the number of Escherichia coli start to decrease since the $10^{\text {th }}$ day and this reduction is accentuated as composting progresses. These faecal bacteria decreased during the thermophilic phase. However, a recontamination was observed at the end of the process, particularly in the windrow W1 (from 5.6 to $6.1 \mathrm{Ulog}_{10} \mathrm{CFUs} / \mathrm{g} \mathrm{WDW}$ ).

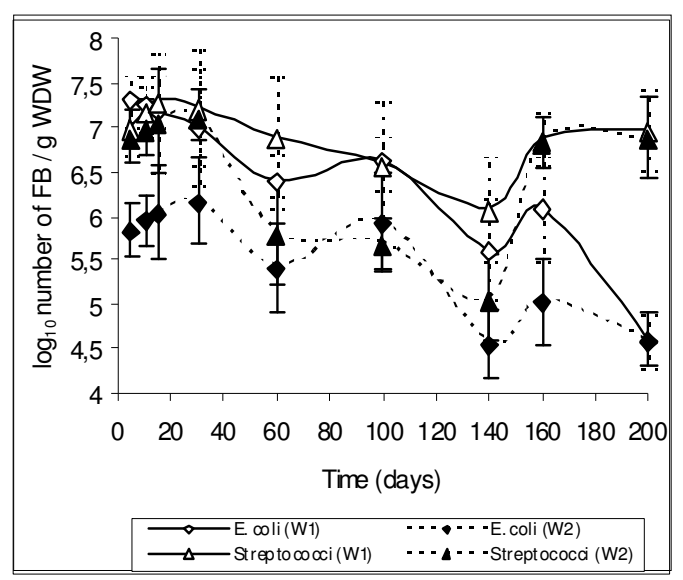

Fig. 5: Progress of faecal indicator bacteria over time in windrows $\mathrm{W} 1$ and $\mathrm{W} 2$.

Faecal streptococci: In this study, the number of faecal streptococci during all the composting process appeared generally more important in the windrow $\mathrm{W} 1$ than in the windrow W2 (Fig. 5). The number of faecal streptococci decreases by 2 and $1 \operatorname{Ulog}_{10}$ on average during the thermophilic phase for windrow $\mathrm{W} 1$ and $\mathrm{W} 2$, respectively. A net increase of the number of streptococci occurs during the cooling phase.

Pathogenic bacteria: Staphylococcus aureus: The identification of Staphylococcus aureus was merely qualitative, of presence-or-absence type. Staphylococcus aureus was only isolated at the start until 30 days of the composting process in the two windrows.

Salmonella: As for Staphylococcus aureus, Salmonella detection was only qualitative (presence or absence). Salmonella was only isolated in the beginning of the composting process in the two windrows and disappeared totally during the later steps of the process. The different isolates of Salmonella were as follow: Salmonella anatum, S. braendrup, S. corvalis and $S$. munchen.

\section{DISCUSSION AND CONCLUSION}

As mentioned above, the composting process showed the three classical temperature steps corresponding to the predominance of the three different communities of microorganisms (mesophilic, thermophilic and mesophilic). The proper balance of nutrients is vital to the composting process, and a good $\mathrm{C} / \mathrm{N}$ ratio of 20 to 35 is generally needed. In this study, the recorded values of $\mathrm{C} / \mathrm{N}$ decreased from 32-18.6 and from 28.5-14.6 for the two windrows $\mathrm{W} 1$ and $\mathrm{W} 2$, respectively, and appeared generally higher in the windrow $\mathrm{W} 1$ than in the windrow $\mathrm{W} 2$. If the $\mathrm{C} / \mathrm{N}$ ratio is above or below the optimum range (25-20), composting proceeds slowly and the excess carbon is converted to $\mathrm{CO}_{2}$ or the excess nitrogen is converted to ammonia, until the correct balance is restored.

On the other side, biological oxidation of different organic substances is generally a dehydrogenation process and there are many enzymes catalyzing dehydrogenation. The dehydrogenase enzyme systems, that are an integral part of the microorganisms, apparently fulfil a significant role in the oxidation of organic compounds as they transfer $\mathrm{H}$ from substrates to acceptors. Several different specific dehydrogenase systems are involved in the dehydrogenase of soils for example. The dehydrogenase activity is proposed as indicator of the maturity of compost and a net decrease of this activity is synonymous of a good stability of biodegradable substances ${ }^{[18]}$. Our result showed that the dehydrogenase activity generally showed an appreciable increase during the period extending between 50 and 140 days and corresponding to the thermophilic active phase of the composting process. The dehydrogenase activity registered in composts W1 and W2 is superior to the threshold of $0.83 \mathrm{mg}$ TPF / $\mathrm{g}$ WDW / d proposed by Forster et al. ${ }^{[18]}$. Serra-Wittling et al. ${ }^{[19]}$ reported a value of $2.3 \mathrm{mg}$ TPF / g WDW / d, in solid waste compost of three months of maturity. As mentioned by Skujins ${ }^{[20]}$, the apparent dehydrogenase activity showed the average activity of the dynamic microbial population and depends on the total metabolic activity of microorganisms. Frankenberger and Dick ${ }^{[21]}$ reported that dehydrogenase activity often is correlated with microbial respiration when exogenous $\mathrm{C}$ sources are added to soils. In addition, some substances may seriously affect the activity of dehydrogenase in composts, mainly volatile compounds frequently found in solid wastes such as $\mathrm{CHCl}_{3}$, Benzene and Toluene. These latter strongly inhibit the activity of dehydrogenase. Ladd $^{[22]}$ reported that some alternate electron acceptors seemed to stimulate $\left(\mathrm{Fe}_{2} \mathrm{O}_{3}\right.$, 
$\left.\mathrm{MnO}_{2}, \mathrm{SO}_{4}{ }^{2-}, \mathrm{PO}_{4}{ }^{3-}\right)$ or to inhibit the apparent dehydrogenase activity in soil $\left(\mathrm{NO}_{3}{ }^{-}, \mathrm{NO}_{2}{ }^{-}\right)$.

The microbial biomass is generally defined as the part of the organic matter in the soil or sediment that is formed by living microorganisms smaller than 5-10 $\mu \mathrm{m}^{3}$. It is an estimate of the amount of solid-phase $C$ or $\mathrm{N}$ tied up in living $\left(\mathrm{B}_{\mathrm{C}}, \mathrm{B}_{\mathrm{N}}\right)$ and dead soil microbes and is essentially an estimate of bacteria and fungi. According to Fig. 3, this $\mathrm{B}_{\mathrm{C}} / \mathrm{B}_{\mathrm{N}}$ ratio increases appreciably during the thermophilic phase in the two windrows and this increase corresponds to a high microbial diversity and equivalent to an important activity.

The enumeration of total viable-cultivable mesophilic bacteria at $28^{\circ} \mathrm{C}$ on Tryptic soy agar permits one to appreciate the microbiological activity during the composting process. This microflora grows in all stages of the organic matter transformation. At the start of the composting process, the average temperature into the windrow is about $30^{\circ} \mathrm{C}$. According to Kaiser ${ }^{[23]}$, the very fast development of mesophilic bacteria would be largely responsible of temperature increase and only thermophilic species will survive. Mesophilic bacteria change and subsist essentially as spores that are why in our result the number of spores showed a notable increase during the thermophilic phase. The number of mesophilic actinomycetes showed in this study no major variation during all the composting process. In composting, actinomycetes play an important role in degrading complex organics such as cellulose, lignin, chitin and proteins. Some species appear as well during the thermophilic phase and others become important during the cooler curing phase, when only the most resistant compounds remain in the last stages of the formation of humus ${ }^{[24]}$. In general, their development at the end of the composting process reaches such intensity that their mycelium and their spores become macroscopically visible, giving to compost a grey colour and a pronounced odour of earth. These appearance and morphological sign of actinobacterial mycelium development were frequently exploited to stop the process of composting in progress and to come to a conclusion about its state of maturation.

On the other side, frequent examinations for the presence of faecal indicator organisms remain the most sensitive and specific way of assessing the hygienic quality of water, soil, organic products, sediments and food. A variety of indicator bacterial species have been evaluated with respect to their reliability as public health indicators, including Escherichia coli and faecal streptococci. These faecal microorganisms are present in big number in various solid wastes and are more easily isolated and identified than the other pathogenic bacteria $^{[25,26]}$. In this study, the number of all type of enteric bacteria studied decreases in generally by 2 and $1 \mathrm{Ulog}_{10}$ on average during the thermophilic phase. However a weak increase of the number of Gramnegative bacteria occurs during the cooling phase. The same result of resumption of faecal indicator bacteria growth was observed by other authors ${ }^{[27,9,2]}$. This recontamination during the cooling phase may be occurring probably during waste turning or it can be the result of occurrence of cold pocket into the mass of wastes that escape the increase of temperature during the thermophilic step. Faecal indicator bacteria considered as potential pathogens reappeared at the end of the composting process (cooling step) and this emergence could constitute a major problem for the agricultural use of compost.

In this study, Staphylococcus aureus and Salmonella were only isolated at the start until 30 days of the composting process in the two windrows and not detected during the later steps of the process. The destruction of pathogenic bacteria such as Salmonella and Staphylococcus aureus can be ensured by two types of operations: temperature increase and antagonism by competing microorganisms ${ }^{[28,29]}$. In the opposite, pathogenic bacteria survival during the composting process was enhanced by reduction in temperature, stabilization of $\mathrm{pH}$ closely neutrality and an increase in dry matter. Brinton and Droffner ${ }^{[30]}$ report that there exist mutants of Salmonella resistant to high temperatures (42 to $54^{\circ} \mathrm{C}$ ) that could recolonize windrows during compost storage. Pereiro-Neta et $a l .{ }^{[31]}$ studied the survival of indicator organisms and pathogens (E. coli, faecal streptococci and Salmonella) in sewage sludge composted with solid municipal wastes and they concluded that static aerated piles were more efficient than windrows in the inactivation of the indicator organisms. E. coli was reduced below the detection level, faecal streptococci were reduced to less than $2 \operatorname{Ulog}_{10}$ CFUs per gram and Salmonella were completely eliminated after 32 days of composting. In contrast, all of these organisms were still detectable at the end of the windrow composting process. Hays ${ }^{[32]}$, however, reported that in a well-managed biosolids windrow composting operation indicator organisms and pathogens including E. coli and Salmonella were destroyed, and Gaby ${ }^{[33]}$ found that Salmonella and Shigella disappeared in windrow composting of municipal solid wastes in 7 to 21 days.

As mentioned above, this study showed in general that the number of microorganisms in windrow $\mathrm{W} 1$ is higher than the number recorded in windrow W2 
supplemented with sewage sludge. This result seems strange because generally dried sewage sludge used is more crowded of microbes than municipal solid waste, and this finding could be explained probably by the presence of toxic and inhibitory elements such heavy metals in the sludge that can slow down and impede the growth and development of autochthonous and native microorganisms existing originally in the municipal solid waste. There is a full competition between the two types of native microbes existing in the two types of solid wastes used in this study, municipal solid waste and dried sewage sludge, respectively. This competition could limit the development, the growth and the biodiversity of microorganisms and acts as a barrier for microbial progress and spreading out inside solid waste.

Finally, the reappearance of bacilli Gram-negative bacteria at the end of the composting process and during the cooling phase, as mentioned above, can be explained by the survival of microorganisms coming generally from the external layer of the windrow which has escaped the thermophilic phase ${ }^{[9,2]}$ or from the potential cold pockets existing into the mass of windrow ${ }^{[34]}$. Low numbers of indicator bacteria allow the assumption that the associated pathogens of particular health concern are not present. It is for this main reason that during the production of compost, microbiological contamination of finished product can constitute a factor of major risk not only for the workmen of the composting plant but therefore for the farmers during compost spreading. At the time of these worker activities in the plant or in the field, there can be ingestion, dermic contact and especially inhalation of aerosols of organic dust carriers of diversified infectious microorganisms (bacteria, actinomycetes, spores, toxins, fungi, virus, parasites) or of many immunoallergic factors (endotoxins and mycotoxins).

A rigorous monitoring of the principal stages and parameters of the composting process and a microbiological control more severe including the measure of viable non cultivable organisms, of endotoxins, of mycotoxins and thermophilic actinomycetes would allow at the same time to a better estimation of the quality of the finished product and a more regular microbiological risk control related to the composting process and to the agronomic valorization of compost.

\section{ACKNOWLEDGMENTS}

This study was supported by the Japan International Cooperation Agency (JICA) within the framework of a research program. We thank the staff of a semi-industrial composting plant of Beja, Mr K. Ben Khedija and Ms N. Tounsi at ANPE for their assistance, cooperation and participation in this study. We are most grateful to Pr H.W. Ackermann (Laval university, Quebec, Canada) for helpful suggestions.

\section{REFERENCES}

1. Holmer, R.J., Gabutin, L.B. and Schnitzler, W.H., 1997. Organic fertilizer production from city waste, a model approach in a Southeast Asian urban environment. Nat. Sci. J., 32: 50-53

2. Hassen, A., Belguigh, K., Jedidi, N., Cherif, M. and Boudabous, A., 2001. Microbial characterization during composting of municipal solid waste. Biores. Technol., 80: 185-192.

3. Bremner, J. M. and Mulvaney, C.S., 1982. Nitrogen total. In: Black C. A., et al. (eds) Methods of soil analysis, part 2. Chemical and microbiological properties. Am. Soc. Agron., Madison, WI. Agron., 9: 595-622

4. Nelson, D.W. and Sommers, L.E., 1982. Total carbon, organic carbon, and organic matter. In Methods of Soil Analysis. Part 2. Agronomy Monographs, ed. A.L. Page et al. American Society of Agronomy, Madison, WI, 539-579.

5. Tabatabai, M.A., 1982. Soil enzymes. Agronomy, 9: 903-947

6. Sparling, G.P. and West, A., 1988. A direct extraction method to estimate soil microbial C: calibration in situ using microbial respiration and ${ }^{14}$ C-labelled cells. Soil Biol. Biochem., 20: 337343.

7. Vance, E.D., Brookes, P.C., Jenkinson, D.S., 1987. An extraction method for measuring soil microbial biomass-C. Soil Biol. Biochem., 19: 703-707

8. Brookes, P.C., Landman, A., Pruden, G. and Jenkinson, D.S., 1985. Chloroform fumigation and the release of soil nitrogen: a rapid direct extraction method to measure microbial nitrogen in soil. Soil Biol. Biochem., 17: 837- 842

9. Hachicha, R., Jedidi, N. and Hassen, A., 1993. Aspects hygiéniques de la fermentation aérobies des déchets urbains dans le contexte tunisien. Arch. Inst. Pasteur Tunis, 70: 13-20

10. El-Nakeeb, M.A. and Lechevalier, H.A., 1963. Selective isolation of aerobic actinomycetes . Appl. Microbiol., 11: 75-77

11. Turco, R.F.,1994. Coliform bacteria. In Methods of soil analysis. Part 2. Microbiological and biochemical propreties. Soil Sci. Soc. Am., 5: 145157. 
12. Rodier, J., 1978. Analyse de l'eau : eaux naturelles, eaux résiduaires, eau de mer. Dunod technique, Edition Bordas, Paris, 1135.

13. De Man, J., 1975. The Probability of Most Probable Numbers. European J. Appl. Microbiol., 1: $67-78$

14. Jimenez, E.I. and Garcia, V.B., 1991. Composting of domestic refuse and sewage sludge. Evolution of temperature, $\mathrm{pH}, \mathrm{C} / \mathrm{N}$ ratio and cation exchange capacity. Resources Conserv. Recycling, 16: 4560.

15. Miller, F.C., 1991. Composting as a Process Based on the Control of Ecologically Selective Factors. In: Metting Jr., F. _. Ed., Soil Microbial Ecology. Applications in Agriculture and Management. Dekker, New York, 515-544.

16. Belete, L., Egger, W., Neunhauserer, C., Caballero, B., Insam, H., 2001. Can Community Level Physiological Profiles be used for Compost Maturity Testing? Compost Sci. Util., 9: 6-18

17. Jedidi, N.; Hassen, A.; Van Cleemput, O. and M'hiri, A., 2004. Microbial biomass in a soil amended with different types of organic wastes. Waste Management and Research, 22: 93-99

18. Forster, J.C., Zech, W. and Wurdiger, E., 1993. Comparison of chemical and microbiological methods for the characterization of the maturity of composts from contrating sources. Bio. Fertil. Soils, 19: 93-99

19. Serra-wittling, C., Houot, S. and Barriuso, E., 1995. Soil enzymatic response to municipal solid waste compost addition. Soil Biol. Biochem., 20: $226-236$

20. Skujins, J., 1976. Extracellular enzymes in soil Crit. Rev. Microbiol., 4: 383-421

21. Frankenberger, W.T.Jr. and Dick, W.A., 1983. Relationship between enzymes activities and microbial growth and activity indices in soil. Soil Sci. Soc. Am. J., 47: 945-951.

22. Ladd, J.N., 1978. Origin and range of enzymes in soil. In R.G. Burns (ed.) Soil enzymes. Academic Press, New York, 51-96. 23

23. Kaiser, D., 1982. L'analyse microbiologique des composts. Compost Information, 10: 9-13

24. Mustin, M., 1987. Le Compost: gestion de la matière organique. Editions François Dubusc. Paris, 953
25. Brinton, W.F. and Droffner, M.W., 1994. Microbial approaches to characterization of composting process. Compost Sci. Utilization, 2, $12-17$

26. Soares, H.M., Cardenas, B., Weir, D. and Switzenbaum, M.S., 1995. Evaluating pathogen regrowth in biosolids compost, Biocycle June, 7076.

27. Alberti, G., 1984. Aspects bactériologiques du compostage des boues résiduaires de stations d'épuration d'eau. Thèse de $3^{\text {ème }}$ Cycle, Université de Nancy I, France. 200

28. Dalzell, H. W., Biddlestone Gray, K.R. and Thurarajan, K., 1987. Soil managment compost production and use in tropical and subtropical environments. FAO Soil Bulletin, 56: 202

29. Finstein, M.S., Miller, F.C., Hogan, J.A. and Strom, P.F., 1987. Analysis of U.S., E.P.A. Guidance on composting waste water sludge. Part II, Biological Process Control. Biocycle, 28: 42-47.

30. Brinton, W.F. and Droffner, M.W., 1995. Evidence for the prominence of well characterisation mesophilic and thermophilic bacteria in thermophilic $\left(50-70^{\circ} \mathrm{C}\right)$ composting environments. Biomass Energy, 8: 3-7

31. Pereiro-Neta, J.T., Stentiford, E.I. and Mara, D.D., 1986. Comparative survival of pathogenic indicators in windrow and static pile. In Compost: Production, Quality and Use. Ed. De Bertoldi, M., Ferranti, M.P., l'Hermite, P. and Zucconi, F. Elsevier Applied Science, London and New York, 276-295

32. Hays, J.C., 1996. Pathogen destruction and biosolids composting. Biocycle, 37: 67-76

33. Gaby, W.L., 1975. Evaluation of health hazards associated with solid waste/sewage sludge mixtures. EPA-670/2-75-023. US Environmental Protection Agency, National Environmental Research Center, Office of Research and Development, Cincinnati, Ohio, USA

34. Pahern, H.R. and Clarck, C.S., 1987. Microorganisms in municipal solid waste and public health implications. Critic. Rev. Environ. Control, 17: 187-228. 